suspicion. Surely any scheme involving the simultaneous observation of two stars at equal altitude from an aircraft must await the arrival of a gyro-stabilized twostar tracker?
Entre Rios 480,
Yours faithfully,
Bella Vista,
J. E. D. Williams.
Buenos Aires.

\title{
SAIL TRAINING FOR NAVIGATION
}

SIR,

I have read with interest Captain C. A. G. Nichols's paper on Collisions and Groundings (Vol. 3 No. 2) and I feel some comment of a general nature may apply.

For some years I have inclined to the view that the ancient caution, wariness and sea-sense of navigators has deteriorated with the advancement of scientific aids and that officers tend to rely on instrumental information to an extent perhaps unwarranted, to the exclusion of experience, skill and senses; i.e. if the scientific answer is ' $x$ ' but experience says ' $y$ ', the former is accepted without demur and the latter dismissed without investigation.

Recent correspondence in a certain periodical questions the preservation of a sailing ship for training purposes and whilst remaining aloof from this subject, I feel that sail-taught navigation, as distinct from seamanship, has considerable merit in that its first essential is caution, its second foresight and its third wisdom: qualities manifestly absent in the navigators mentioned by Captain Nichols. Had it been otherwise, they might not have walked into traps so obviously baited.

In the case of the two motorships, captain 'A' had a great asset which, coupled with the above qualities, ought to have made collision well-nigh impossible. But his justifiable confidence in radar obscured his judgement and he appears to have mistaken knowledge for wisdom. In the absence of radar I am sure he would have acted with the utmost circumspection; and had he exercised the same with his scientific aid, short of Act of God, he was safe. Knowing merely the presence and whereabouts of a ship calls, I think, for prudence as hitherto adopted rather than for reliance upon the instrument which itself does not pretend to be collision proof.

The Queen Mary case appears to me to be one due to lack of foresight on both sides. Perhaps her officers, being over-familiar, did not fully appreciate her weight and speed of about 50 feet per second on an erratic course or that she was, in fact, a most undesirable companion. Certainly her responsible officer had never taken a brisk walk with a free puppy in front of his feet else he would have expected the inevitable, and it may be callous to regret that in his youth the cruiser's captain had never apparently run a tight race with a bull. Queen Mary appeared determined to complete her leg to the last yard notwithstanding the jeopardy, and she seems to have lost sight of the salient point-that the zig-zag was designed for safety and when no longer safe its function had passed for the moment.

As regards the vessel in-bound to the Clyde; making a landfall in blowing weather carrying a dead reckoning two days old and with a lee shore most uninviting demands, I think, methods a little less happy-go-lucky than those adopted by this ship. 
If the captain had faith in his reckoning then he should have queried the soundings; if he doubted his position then he should have got a sounding or, if no bottom, cast until he found it. The errors in reckoning might have been cancelled had he done so but I fear he was more modern than some of the old navigators who, when approaching a continental shelf on a dead reckoning, backed the main yard and got one of two things-a sounding or 100 fathoms and No Bottom. One cannot blame the echo gear for being broken but only the deplorable lack of caution displayed.

The ship navigating the Norwegian coast had an easy remedy: a good bold offing with the utmost despatch at the onset of fog. I am at a loss to discover the reason for standing in so as to hear a fog signal. What did she expect to do with it when obtained? Did her captain want to know just how much too close he was? Of one thing, however, I am certain; he didn't suffer with heart trouble else, had he heard it, he would have dropped dead. Had he enquired for the land in a sailing craft he would have been advised to try the masthead, a recommendation not entirely inapplicable in these steam days.

The officers of the vessel entering Kingston are entitled to sympathy, I think. Islands, though conspicious on the chart, may be anything but obvious at sea level if viewed against a terrestrial background or in certain atmospheric conditions and I feel sure that in this case, had there been no background, no mistakes would have been made, notwithstanding the somewhat haphazard programme of entry. No doubt, if the circumstances were as I suggest, a caution over and above that normally required should have been exercised.

Perhaps the philosophy of an old friend of mine has an application in these scientific times. He navigated a schooner in waters where the weather came out of the blue. He slept with the utmost equanimity after heaving the barometer overboard.

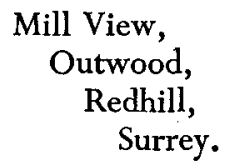

Yours faithfully,

RONALD G. Bolton. 